\title{
Article \\ Current Legislative Framework for Green Hydrogen Production by Electrolysis Plants in Germany
}

\author{
Lena Maria Ringsgwandl ${ }^{1, *}$, Johannes Schaffert ${ }^{2, *}$, Nils Brücken ${ }^{2, *}$, Rolf Albus ${ }^{2}$ and Klaus Görner ${ }^{2}$ \\ 1 ALBA Group, 10719 Berlin, Germany \\ 2 Gas-und Waerme-Institut Essen e.V. (GWI), Hafenstrasse 101, 45356 Essen, Germany; \\ rolf.albus@gwi-essen.de (R.A.); klaus.goerner@gwi-essen.de (K.G.) \\ * Correspondence: lena.ringsgwandl@albagroup.de (L.M.R.); johannes.schaffert@gwi-essen.de (J.S.); \\ nils.bruecken@gwi-essen.de (N.B.)
}

check for updates

Citation: Ringsgwandl, L.M.; Schaffert, J.; Brücken, N.; Albus, R.; Görner, K. Current Legislative Framework for Green Hydrogen Production by Electrolysis Plants in Germany. Energies 2022, 15, 1786. https://doi.org/10.3390/en15051786

Academic Editor: Attilio Converti

Received: 31 January 2022

Accepted: 20 February 2022

Published: 28 February 2022

Publisher's Note: MDPI stays neutral with regard to jurisdictional claims in published maps and institutional affiliations.

Copyright: (C) 2022 by the authors. Licensee MDPI, Basel, Switzerland. This article is an open access article distributed under the terms and conditions of the Creative Commons Attribution (CC BY) license (https:// creativecommons.org/licenses/by/ $4.0 /)$.

\begin{abstract}
The German energy system transformation towards an entirely renewable supply is expected to incorporate the extensive use of green hydrogen. This carbon-free fuel allows the decarbonization of end-use sectors such as industrial high-temperature processes or heavy-duty transport that remain challenging to be covered by green electricity only. However, it remains unclear whether the current legislative framework supports green hydrogen production or is an obstacle to its rollout. (2) This work analyzes the relevant laws and ordinances regarding their implications on potential hydrogen production plant operators. (3) Due to unbundling-related constraints, potential operators from the group of electricity transport system and distribution system operators face lacking permission to operate production plants. Moreover, ownership remains forbidden for them. The same applies to natural gas transport system operators. The case is less clear for natural gas distribution system operators, where explicit regulation is missing. (4) It is finally analyzed if the production of green hydrogen is currently supported in competition with fossil hydrogen production, not only by the legal framework but also by the National Hydrogen Strategy and the Amendment of the Renewable Energies Act. It can be concluded that in recent amendments of German energy legislation, regulatory support for green hydrogen in Germany was found. The latest legislation has clarified crucial points concerning the ownership and operation of electrolyzers and the treatment of green hydrogen as a renewable energy carrier.
\end{abstract}

Keywords: hydrogen; power-to-hydrogen; power-to-gas; energy law; energy regulation; renewable energy; legal framework; energy; energy transition; electrolysis

\section{Introduction}

Hydrogen as an energy carrier can be used as a fuel that reacts without causing harmful emissions. When hydrogen is reacted with pure oxygen, the reaction product is water only, making hydrogen a unique fuel. The broad use of pure hydrogen is a promising future scenario for various end-use sectors, especially those that cannot easily cover their energy demands by renewable electricity. Prominent examples are in heavy-duty transportation, such as trucks, ships, or trains, and industrial high-temperature processes. Finally, the admixture of hydrogen into natural gas is also discussed as an option [1] to partly decarbonize all end-use sectors, including all gas-fired domestic and commercial technologies, before a mass rollout of dedicated pure hydrogen technologies can be realized.

Besides its unique characteristics as a fuel, hydrogen's second essential advantage is that it can be produced using only renewable electricity and water. The process is often referred to as "power-to-hydrogen", or more generally "power-to-gas" (PtG). The resulting renewable hydrogen-in the following referred to as green hydrogen-can be transported and stored in analogy to the proven natural gas technologies [2] and, thus, serve as a large-scale option to convert and store renewable electricity to cover renewable energy demands all around the year. 
Academia, industry, and governments are constantly developing strategies to roll out hydrogen technologies, some of which have reached high technology readiness and are all set for mass production. However, in the existing energy systems, with all the interdependent entanglements of existing laws, regulations, infrastructures, and end-use applications, the market for hydrogen technologies is not developing swiftly. Until recently, decision-makers in Germany faced a lack of planning reliability due to missing legal and regulatory frameworks in combination with high technology cost. In addition, unclear future prospects, e.g., concerning prices, fees, and tariffs levied for the electricity needed for green hydrogen production, acted as barriers to investment decisions. The regulatory framework in Germany has been improved in 2021, providing more reliability. However, business models are still missing, and some aspects that appear crucial from the societal perspective, such as the long-term storage option of renewable energy in gaseous form, are not met by today's regulatory framework in Germany.

The situation is even more complex since different qualities of hydrogen could potentially be available from domestic production or imports, which could diverge dramatically in terms of environmental footprints. Depending on the environmental footprints and prices of available hydrogen on the market, different consumer groups are expected to show varying levels of acceptance.

This work reviews, analyses, and discusses the current situation for the case of Germany in 2021 with a focus on the two following research questions: Do German laws and regulations support hydrogen produced from renewable electricity (green hydrogen) in its competition with grey, blue, turquoise, or pink hydrogen? Do German laws and regulations support green hydrogen in its potential role as a long-term renewable energy storage option?

\section{Materials and Methods}

This work reviews and assesses the current legal framework for hydrogen in Germany. The corresponding central laws and acts as well as the national hydrogen strategy are discussed:

- $\quad$ Energy Industry Act (EnWG, 2021) [3];

- $\quad$ Renewable Energies Act 2021 (EEG, 2021) [4];

- $\quad$ Renewable Energies Ordinance (EEV, 2021) [5];

- $\quad$ National Hydrogen Strategy (NHS, 2020) [6].

\section{Results}

\subsection{Hydrogen-Technology Options for Its Production and the Resulting "Color Scale"}

In this section, the different possibilities to produce hydrogen are presented. Figure 1 shows the processes, educts, by-products, and "color" of the product hydrogen. The color theory is intended to reflect the degree of sustainability of the hydrogen produced. While hydrogen from fossil natural gas is turquoise, blue, or grey, hydrogen produced from biomass and biogas is green. Hydrogen from the electrolysis process, which is the focus of this paper, is also considered green hydrogen when renewable electricity sources are used, yellow when the electricity mix is used, and pink when nuclear electricity is used. The different production processes and the respective technology readiness levels (TRLs) are described in more detail below. 

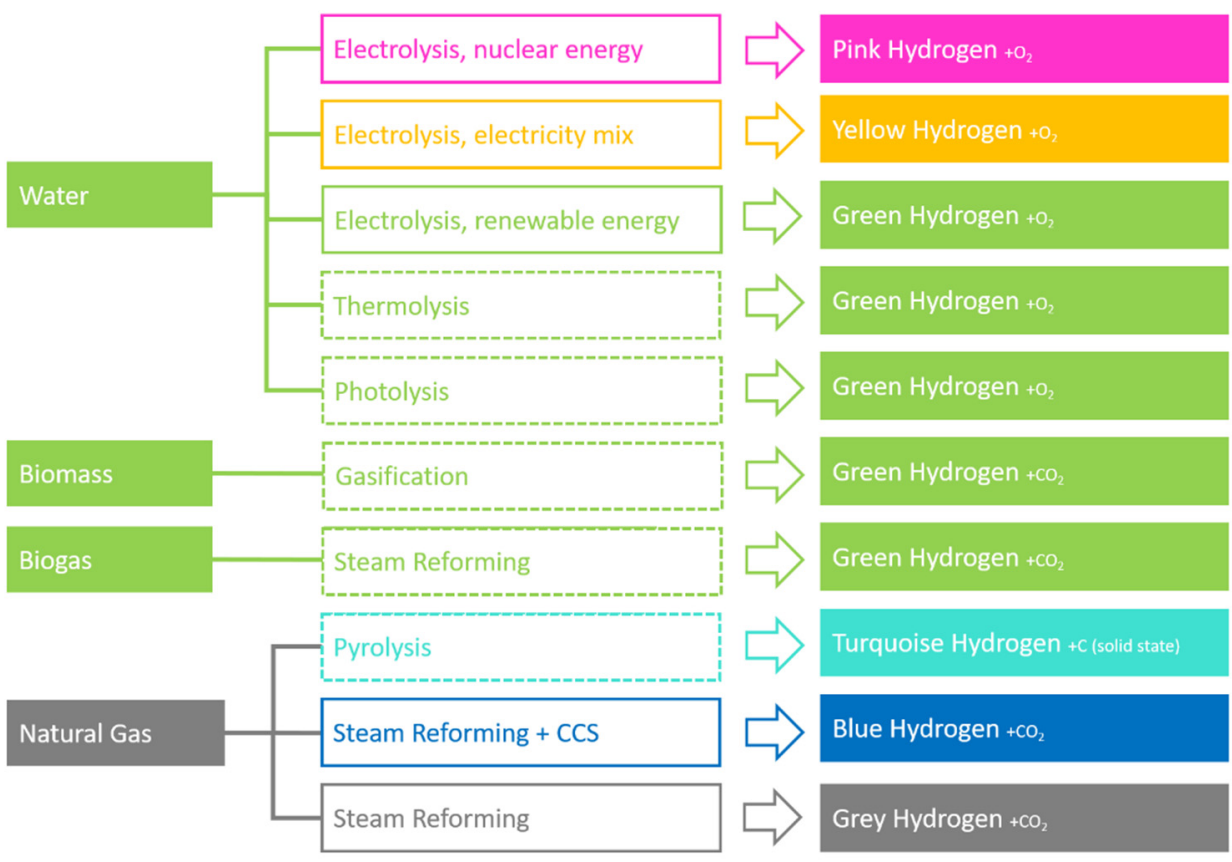

Figure 1. Overview of possible hydrogen production pathways using various technology options and electricity sources. Dashed boxes indicate technologies that are not yet available on an industrial scale.

In the electrolysis process, water is split into its components hydrogen and oxygen by the addition of electrical energy. Alkaline electrolysis (AEL) (TRL 8-9) [7], proton exchange membrane electrolysis (PEMEL) (TRL 8-9) [7], and high-temperature electrolysis (HTE) (TRL 5) [8] are known as common electrolysis technologies. While AEL and PEMEL have already been in operation for many years, HTE plants are still in the development stage, and HTE is characterized in particular by a high operating temperature of $700-1000{ }^{\circ} \mathrm{C}$ [8]. The main difference between AEL and HTE is the high temperature of the electrolyte. Essentially, AEL differs from the solid electrolyte of PEMEL by its additional caustic circuit, which transports the liquid electrolyte. While AEL has been used on a large scale for many decades, PEMEL has only been installed in the MW range for a few years. One advantage of AEL is the comparatively low specific plant costs. PEMEL is characterized by a more compact design and better dynamics, which means more flexible operating point changes, especially when renewable electricity is purchased. In addition to hydrogen, there is the possibility of removing the process heat and oxygen as by-products. As can be seen in Figure 1, the color of the hydrogen depends on the electricity used. Thus, pink hydrogen can be produced by using nuclear energy, yellow hydrogen by using the public electricity mix, and green hydrogen by using renewable electricity.

Thermolysis describes the process at temperatures above $1500{ }^{\circ} \mathrm{C}[9]$ with which the thermal decomposition of water into its components hydrogen and oxygen begins. Thus, it is theoretically possible to obtain hydrogen directly from water vapor at a very high temperature level. Challenges include technically controlling the working temperature, separating hydrogen, and avoiding direct recombination with oxygen back to water. Lowering the temperature of thermal water splitting can be achieved through coupled chemical reactions based on so-called metal oxide redox systems. The TRL for thermolysis is currently about 2 to 5 [8-10].

In photolysis, sunlight is used with the aid of a catalyst to effect direct water splitting. In 1972, Japanese scientists Fujishima and Honda discovered that titanium dioxide was suitable as such a catalyst [11]. Although worldwide efforts have been made since then to better understand the process flow as well as how the catalyst works, there is still a lack of understanding to achieve major efficiency improvements. Photolysis, like thermolysis, is at a low TRL (about 3) [10]. 
Biomass gasification describes a process in which biomass is supplied with heat, steam, and oxygen in a controlled manner and converted into hydrogen as well as other products. The biomass gasification process runs at temperatures of $>700{ }^{\circ} \mathrm{C}$ without combustion. Organic or fossil carbonaceous materials are converted into carbon monoxide, hydrogen, and carbon dioxide with controlled amounts of oxygen and steam. One of the major challenges in hydrogen production using biomass gasification is the reduction in investment costs for the plant as well as for the biomass feedstock. The dual fluidized bed gasification (DFB) concept from the Vienna University of Technology is a promising approach to biomass gasification. The TRL for the DFB is currently 5 [12].

Steam methane reforming (TRL 9) [13] is today's standard in large-scale hydrogen production, usually found in industrial contexts, such as the chemical industry. Steam reforming uses methane (natural gas) which is thermally decomposed into $\mathrm{CO}$ and $\mathrm{H}_{2}$ by hot, pressurized water steam in presence of a suitable catalyst. The water-gas shift reaction then leads to more $\mathrm{H}_{2}$ output and $\mathrm{CO}_{2}$ formation before, in a final step, the two are separated, e.g., by a pressure swing adsorption. The resulting hydrogen from today's largescale plants is "grey hydrogen". However, renewable methane from biogenic sources that are connected to a large-scale gas processing plant by collection lines could be a technology option to produce "green hydrogen" via steam reforming as well. Steam reforming is therefore represented twice in Figure 1. The carbon dioxide emissions resulting from steam reforming plants could be reduced by integrating carbon capture technologies, which are not yet state-of-the-art (TRLs 7-8) [13,14].

Finally, one more alternative approach for hydrogen production is the technology class of pyrolysis. Here, hydrogen is provided by separating the carbon components from the methane molecules. Since the process is endothermic, heat must be added, for example in processes that use hot liquid metal baths to crack the molecules $[15,16]$ at technology readiness levels in the range of 3-5 [13]. Other processes work, for example, with electron beam plasmas to split the methane molecules but are at a very early stage of development (TRLs 2-3) [14]. Pyrolysis technologies could be options for very large scale hydrogen production plants in the hundreds of megawatts order of magnitude. Due to their suitability for large-scale application, pyrolysis is combined with natural gas conversion in Figure 1, producing the so-called "turquoise hydrogen". This fossil-based hydrogen variant is to be distinguished from the "grey hydrogen" since its by-product carbon accumulates in solid form. Unlike gaseous $\mathrm{CO}_{2}$, for example, the chemically inert solid carbon is prevented from reaching the atmosphere and acting as a greenhouse gas. In contrast, solid carbon products such as carbon black can be sold as dyes for specific industries.

\subsection{Current Techno-Economic Situation of Green Hydrogen Production}

The production of green hydrogen-for energy storage or other uses-is not yet economically viable or competitive in the market. The economic competitiveness of green hydrogen production mainly depends on the cost of electrolyzers, the cost of renewable electricity used in the process, the load factor (operating hours per year), and the plant scale [17-20]. With regard to the German legal situation, the price of electricity from renewable energy sources (RESs) is most interesting. The cost of RES power has generally decreased in recent years [21], meaning the production costs of green hydrogen could also drop. Currently, however, Germany has one of the highest electricity prices worldwide [22], which is a hindrance to the economic feasibility of green hydrogen production. Taxes and levies are a large part of the electricity price in Germany (accounting for approximately $50 \%$ of the electricity price for household consumers) [23]. Thus, any exceptions to any of the imposed levies are a major concern for PtG plant operators.

\subsection{Introduction: German Energy Industry Act (EnWG) and Renewable Energies Act (EEG)}

To a large extent, German energy law is formed by European (i.e., European Union) law. While we will not examine European energy law in itself, it plays an important role in German legislation and the interpretation of German energy law. While the European 
treaties were important in setting ground rules for a common European energy market, the EU's directives and regulations are most important in providing common regulation for the EU's member states. Both kinds of regulation are binding for the member states; directives, however, are not binding for European citizens until the member state has transposed them into national law (which they are obligated to do). Regulations, on the other hand, are directly binding for member states and citizens, much like national laws.

The two central laws for the development of green hydrogen in German energy legislation are the Renewable Energy Sources Act (EEG 2021) and the Energy Industry Act (EnWG).

The EEG 2021 (with predecessing laws going back to the 1990s [24]) governs the promotion of renewable energy sources for electricity production. It is meant to extend electricity production from renewable sources and to keep the overall cost of energy at a low level (§ 1 (1) EEG 2021). To this end, it provides two main instruments:

- An obligation of the transmission system operators (TSOs) to provide network access;

- $\quad$ An obligation of TSOs to pay either market premiums or feed-in tariffs to the producers for renewable electricity fed into the system.

Both instruments are designed to offer renewable energy producers a reliable legal and financial basis for their investments.

The market premiums or feed-in tariffs are financed via the "EEG surcharge". It is charged as part of the electricity price and is thus paid for by the electricity consumers.

The EnWG, on the other hand, is not limited to energy from renewable sources. It provides an overall framework for a functioning, competitive energy market (§ 1 EnWG). Among other things, it regulates the operation of energy networks (electricity and gas) and the tasks of TSOs and distribution system operators (DSOs). It further includes rules on the unbundling of network operators, storage facility operators, and suppliers, as well as rules for grid connection and the powers of the regulatory authority.

The EnWG also is the basis for a number of ordinances regarding grid access charges. We will also discuss the unbundling regulations as they pertain to the question of which players in the market are allowed to run an electrolyzer/PtG plant under German law.

\subsection{Applicability of the EnWG to Hydrogen}

German legislation has recently moved forward with regard to hydrogen production. Its objective in § 1 EnWG now mentions the supply of hydrogen. Hydrogen is also mentioned as one type of energy (see definition in $\S 3$ No. 14), albeit only as far as it is used in "grid-bound" energy supply.

Hydrogen falls under the EnWG's definition of gas according to $§ 3$ No. 19a EnWG; however, the definition only applies to hydrogen if it is made from water electrolysis and injected into the gas grid. $\$ 3$ No. 19a makes no mention of the electricity source used for the electrolysis process, meaning that not only green hydrogen is encompassed. However, neither grey nor blue hydrogen is included.

Hydrogen also falls under the EnWG's definition of biogas ( $\$ 3$ No. 10c EnWG), provided it is produced via water electrolysis using electricity predominantly from renewable energy sources [25-27].

As for energy storage via green hydrogen, the amended EnWG now defines "hydrogen storage plants" in $\S 3$ No. 39b. They are defined as plants for the storage of hydrogen in ownership of or in operation by an energy supply undertaking. Hydrogen storage plants of hydrogen grid operators for their tasks are not encompassed by this definition and are not hydrogen storage plants according to $\S 3$ No. 39b EnWG.

\subsubsection{Ownership and Operation of Power-to-Hydrogen Plants: Unbundling Regulations}

The energy market is highly regulated in Germany. There are strict rules on which players can or cannot-for example-operate electricity generation facilities, operate energy networks, or sell/supply energy. How these regulations apply to hydrogen production/PtG facilities is important to potential operators, investors, and network operators alike. 
Unbundling regulations are to be found in $\S \S 6-10$ EnWG. They transpose binding European unbundling legislation into German national law [28]. Unbundling generally is the idea that the operation of gas/electricity networks (distribution and transmission networks) has to be separated from electricity/natural gas generation and supply. The reason behind this is that network operation is a natural monopoly while generation and supply are competitive activities. Therefore, DSOs and TSOs must not be in a position to exploit their position as monopolists and unfairly influence the generation/supply market [29].

According to § 6 (1) EnWG, any network operator (NO), i.e., TSO or DSO, has to be independent from any kind of electricity/gas generation or supply. The EnWG does not allow the operation for NOs. Instead, it prescribes ownership unbundling for these activities [30].

The latest amendment to the EnWG now includes a definition of energy storage facilities ( $\$ 3$ No. 15d), which was missing from the EnWG before. Are PtG plants energy storage facilities and, if so, is this of any consequence for hydrogen energy storage? § 3 No. 15d EnWG now defines energy storage facilities. They are "facilities consuming electrical energy for electrical, chemical, mechanical or physical intermittent storage and reproduce it as electrical energy or in another form of energy". This wording includes PtG plants producing green hydrogen for energy storage. The official justification for the new amendment (BR-Drs. 165/21 v. 12.02.2021) [31] explicitly mentions PtX (power-to- ... technologies, including PtG).

There has been some discussion about whether or not NOs should be allowed to own or operate electrolyzers $[16,25,27,29]$. The latest amendment of the EnWG, however, has largely rendered this question moot as far as TSOs and electricity DSOs are generally concerned.

According to $\S 7$ (1) EnWG, electricity DSOs are not allowed to own an energy storage facility or to build, manage, or operate one. According to § 8 (2) EnWG, electricity TSOs are not allowed to own an energy storage facility or to build, manage, or operate one. $\S 10 \mathrm{~b}$ (3) EnWG holds a similar regulation for TSOs within a VIU. Notice it is not gas NOs that are forbidden from engaging in energy storage facilities. The official justification merely states that the rules for gas NOs in this regard are "the general regulations" [31]. Natural gas network operators also have to abide by the unbundling regulations according to $\S \S 6$ ff. EnWG; hence, the reasonable legal assessment is that they are also not allowed to engage in the ownership or operation of an electrolyzer [19,30].

There is an exception to the prohibition for electricity network operators: $\S 11 \mathrm{a}$ (1) EnWG says that electricity NOs are allowed to build, manage and operate energy storage facilities under certain circumstances. The energy storage facility has to be owned by a third party. The construction, management, and operation have to be tendered in an open and fair procedure. All of this only applies if the energy storage facilities are necessary for the NO to fulfil its duties according to § 11 (1) EnWG. These are to run a secure, reliable, and effective network in a non-discriminatory way and to maintain it, optimize it according to demand, and augment and expand it, as far as is economically reasonable.

$\S 11 \mathrm{~b}$ EnWG states that in certain cases, an electricity NO may own energy storage facilities or operate, build or manage them, if the regulatory authority gave permission to do so or if the regulatory authority allowed it for several or all NOs according to $\S 29$ EnWG. This applies only to energy storage facilities that are fully integrated network components. Both § 11a and § 11b EnWG only apply to energy storage facilities that can produce electric energy. NOs could only make use of electrolyzer exceptions if they also re-electrify the hydrogen.

An example that the (green hydrogen) market has already tried these regulations is the decision made by the Federal Network Agency regarding the project "ELEMENT EINS" [32]. The planned project was to build a large-scale electrolyzer for the production of green hydrogen. The project partners were three network operators (one electricity TSO, two natural gas TSOs). The two natural gas TSOs were to build and operate the electrolyzer, and all three applicants would offer network access to their respective networks. The 
application pertained to the investments necessary for the project and their financing via network fees. After long consideration, the Federal Network Agency denied the application for the project because the operation of such a plant was not within the original tasks of network operators. The agency found among other considerations that the construction of the electrolyzer was not necessary for the expansion of the supply network according to $\S 11$ EnWG. $\S 11$ (1) EnWG obliges NOs to run and also optimize or expand their networks as needed. The Federal Network Agency did not see the construction of the electrolyzer as part of the applicants' duties. Furthermore, the agency saw the possibility that the operation of the electrolyzer by an NO might be a risk to the network operation itself. Since the successful operation of the electrolyzer depends on congestions in the network, the NO might therefore have less of an incentive to secure an efficient and safe network in the first place. It should be kept in mind that the application was aimed at the financing of the electrolyzer investment costs via network fees. According to the Agency, this could discriminate against other potential electrolyzer operators, which do not have the possibility of offsetting their costs via network charges.

Since the time the Federal Network Agency issued the decision, the unbundling legislation in the EnWG was amended, as seen above for $\$ \S 11$ a, b EnWG. This begs the following question: would the Federal Network Agency issue a different decision today? In its decision, the Federal Network Agency stressed specifically that the legislator had not assigned the operation of an electrolyzer to an NO. This has changed to some degree as the legislator has now specifically prohibited the ownership and operation of energy storage facilities for electricity NOs (§ 7 EnWG). If the exemptions of $\S \S 11$ a and b EnWG do not apply, there is still no way for an electricity NO to operate an electrolyzer. For natural gas NOs, there has been no change in legislation, and the decision would probably be issued in the same way now.

An overview of the current regulatory status of potential electrolyzer owners and operators in Germany is given in Table 1.

Table 1. Regulation of ownership and operation of electrolyzers in Germany for potential stakeholders.

\begin{tabular}{ccc}
\hline Stakeholders & $\begin{array}{c}\text { Ownership or Operation } \\
\text { of Electrolyzers }\end{array}$ & Further Explanations \\
\hline TSOs (natural gas) & $\begin{array}{c}\text { No explicit regulation in German law; } \\
\text { most probably not admissible. }\end{array}$ & See Section 3.4.1 \\
\hline DSOs (natural gas) & $\begin{array}{c}\text { No explicit regulation in German law; } \\
\text { most probably not admissible. }\end{array}$ & See Section 3.4.1 \\
\hline TSOs (electricity) & $\begin{array}{c}\text { No ownership or operation of } \\
\text { electrolyzers permitted: §§ 6, 8 EnWG. } \\
\text { Exceptions possible: } \S 11 \text { a and b EnWG. }\end{array}$ & See Section 3.4.1 \\
\hline DSOs (electricity) & $\begin{array}{c}\text { No ownership or operation of } \\
\text { electrolyzers permitted: } \S \S 6,7 \text { EnWG. } \\
\text { Exceptions possible: } \S 11 \text { a and b EnWG. }\end{array}$ & $\begin{array}{c}\text { For exceptions from charges } \\
\text { see Section 3.5.3 }\end{array}$ \\
\hline Third parties, e.g., \\
plant manufacturers
\end{tabular}

\subsubsection{Grid Tariffs}

Energy storage facilities are generally considered "final customers" in terms of electricity consumption [28]. The EnWG defines final consumers as "natural or legal persons purchasing energy for their own use" [28]. In this sense, PtG plant operators are final consumers since they purchase energy (electricity) for their own use. However, subjecting them to all the regular levies also means that the costs for running a PtG plant for storage might be high. There is also a definition of wholesale customers ( $\$ 3$ No. 21 EnWG) defining wholesale customers as "a natural or legal person purchasing electricity for the purpose of resale inside or outside the system where it is established" [28]. This definition seems to be 
a little closer to the business model of an energy storage plant than the definition of a final consumer [28]; however, the wording does not fit-electrolyzer operators might not buy electricity primarily to resell it but actually to store it. The prevailing legal opinion is that energy storage plant operators are to be classified as final consumers [28].

There is a general obligation to pay network fees according to $§ 21$ (1) EnWG. Usage of the grid occurs when taking power from the grid as well as feeding it into the grid. There is, however, an exception to this rule which applies to electrolyzer plants. § 118 (6) EnWG provides that plants constructed after 2008 and beginning operation on or after 4 August 2011 are exempted from network access fees regarding the electricity taken for storage. This expressly includes PtG plants [33]. § 118 (6) EnWG does not include an exception from feed-in fees for feeding electricity into the grid (from a PtG plant); this, however, is covered by § 15 (1) StromNEV (electricity network fee regulation ordinance): there are no charges for the injection of electricity. It should be noted that $\S 15$ StromNEV applies to electricity of any source, not just renewable sources. Therefore, $§ 15$ StromNEV does not constitute a privilege.

\subsection{Green Hydrogen Production under the EEG 2021}

In the 2021 amendment of the Renewable Energies Act, hydrogen is taken into account to a larger degree. Before, the electricity supply for green hydrogen production was not exempted from surcharges. The amendments will be described in detail in the following subsections.

\subsubsection{Applicability of the EEG 2021 to Hydrogen}

The EEG 2021 governs the promotion of energy from renewable sources. One of its objectives is the system integration of electricity from renewable sources (RES) (\$§ 1, 2 EEG 2021). The EEG contains support schemes for RES, which directly affect the cost of electricity consumed for green hydrogen production and will be assessed in the following.

Does green hydrogen qualify as renewable energy according to § 3 No. 21 EEG 2017? "Renewable energy" according to this provision is, among others, "energy from biomass including biogas, bio methane ( . . )" (see $\S 3$ No. 21 in [34]). Hydrogen of any kind is not named in the provision. It does not fit under this regulation because it is not derived from biomass, but also not biogas. § 3 No. 11 EEG 2021 defines biogas as "any gas obtained from anaerobic fermentation of biomass". Biomass is not actually defined in the EEG 2021 [35]. However, the official justification of the EEG 2009 gives an indication: Biomass encompasses "biogenic energy carriers in solid, liquid or gaseous form" [36], which have to be biodegradable and generally derived from plant or animal origin [36]. Hydrogen is none of these things and therefore does not fall under this definition of "renewable energy". It has been argued that one could draw an analogy and thus subsume hydrogen under the term "biogas", with the reasoning being as follows: the EEG's objective is to promote climate and environmental protection, and, to that end, to promote the use of renewable electricity and the development of suitable technologies (see § 1 (1) in [33,34]); because of this, green hydrogen should also be subsumed under biogas since it has all the attributes and functions of biogas [33]. While this argumentation may appear preferable for the development of green hydrogen production in Germany, the reasoning lacks justification. In German law, an analogy requires an accidental gap in regulation, in other words, that the legislator would have included hydrogen if he had only remembered to do so. This might have been the case for the EEG 2017; however, the legislator for the EEG 2021 clearly made an amendment to include green hydrogen in other regulations (see § 69b EEG 2021). Therefore, hydrogen does not qualify as biogas in the sense of the EEG 2021.

It is important to underline the difference between the two relevant laws since in contrast to the EEG 2021, the EnWG does qualify hydrogen as biogas. This is due to different definitions of the term "biogas". Hence, it is important to apply this term only with clear reference to one law and not to assume that the EnWG and the EEG 2021 employ the same definitions. 


\subsubsection{The EEG Surcharge}

Since the operating expenditures are a crucial and potentially hindering factor in the economic viability of hydrogen production, we should take a closer look at the charges and levies that apply for green electricity supply.

The EEG surcharge serves the purpose of promoting renewable energies in Germany. It is part of the electricity price and as such has to be paid by the electricity consumers. The revenues created from the EEG surcharge are used to pay certain remunerations for operators of renewable energy, i.e., to electricity generators. The plant operators feed electricity into the power grid and receive fixed remunerations from the TSO. The TSO in turn is reimbursed via the revenues from the EEG surcharge [37].

Since electrolyzers draw power from the grid, they are considered "final consumers" (see $\S 3$ No. 33 EEG 2021). Consequently, they fall under the scope of $\S 61$ (I) EEG 2021 and thus have to pay the EEG surcharge as part of the electricity price. This does not seem reasonable for plant operators, since they argue their purpose is the storage of electricity, not consumption. The last amendment of the EEG has improved this situation, however. $\S 61$ (II) EEG 2021 stipulates that under certain circumstances, the EEG surcharge can be reduced or be omitted completely. For electrolyzers, it refers to § 69b EEG 2021 (titled "production of green hydrogen"). This exemption will be explored in the following section.

\subsubsection{Exemption from the EEG Surcharge}

$\S 69 \mathrm{~b}$ EEG 2021: Green hydrogen production

$\S 69$ b EEG 2021 exempts PtG plants from the duty of paying the EEG surcharge. There are several requirements to be met in order to qualify for the exemption. First, it only applies to the electricity used for the production of green hydrogen. This begs the following question: what exactly qualifies as green hydrogen? The EEG 2021 itself does not define green hydrogen. $\S 69 \mathrm{~b}$ stipulates that the exemption is only applicable when an ordinance has given detailed requirements for the qualification of green hydrogen. As of July 2021, an (amended) ordinance is in force: the "Ordinance for the implementation of the renewable energies act and the wind power at sea act" (also renewable energies ordinance, EEV, [5]). $\S \S 12 \mathrm{~h}-12 \mathrm{EEV}$ apply to green hydrogen. The objective of the new regulations is to exempt certain hydrogen production plants from the EEG surcharge, thus making electricity cheaper to them and eventually rendering the electrochemical production of green hydrogen more economically feasible and competitive [5].

Green hydrogen according to § 69b EEG 2021 is hydrogen made within the first 5000 full-load hours of the year (calendar year) in a green hydrogen production facility. According to $\S 12 \mathrm{i} E E V$, it is required that the production uses exclusively electricity that:

- Verifiably stems from renewable energy production plants (§ 3 No. 21 EEG 2021);

- Stems verifiably at least $80 \%$ from plants within the German bidding zone; $20 \%$ at the most may come from plants within a bidding zone electrically connected to the German bidding zone;

- Was not produced receiving any payments or support according to the EEG, the EEV, or the Combined Heat and Power Act (CHP Act) [38].

$\S 12 i$ (2) EEV gives further definition regarding electricity stemming from renewable energy plants. Renewable energies according to § 3 No. 21 EEG 2021 are, among others, hydropower, solar power, energy from biomass, and geothermal energy. § 12i (3) EEV gives instructions for the calculation of full-load hours. It is irrelevant for which purpose the hydrogen is produced. Furthermore, § 69b EEG 2021 only applies to facilities taken into operation before 1 January 2030. According to $\S 12 \mathrm{~h}$ EEV, exemptions apply to electricity used from 1 January 2022 on [5].

$\S$ 64a EEG 2021: Limitation for undertakings with intensive electricity costs

There is another option to reduce the EEG surcharge for green hydrogen production. $\S \S 63$ No. 1 a, 64a EEG 2021 offers a limitation of the EEG surcharge to be paid by PtG plant operators. It applies to hydrogen production plants qualifying as undertakings with intensive electricity costs. 
A short digression in order to explain the notion of "undertakings with intensive electricity costs" is as follows: The limitation of the EEG surcharge is an established instrument within the EEG's regime. Companies in certain industries (e.g., railroad, production of goods, mining, see annex 4 to EEG 2021) can apply for the limitation, provided they meet certain requirements. The objective is to keep these companies competitive in the market and to prevent them from moving their operation abroad.

According to $\S \S 63$ No. 1a, 64a EEG 2021, companies producing hydrogen electrochemically are also eligible for this kind of EEG surcharge limitation. The limitation applies to hydrogen production for energy storage since $\S 64$ a (1) EEG 2021 states that the regulation applies regardless of the intended usage of the hydrogen. It is interesting that $\S 64 a \mathrm{EEG}$ 2021 does not make any demands regarding the source of the electricity used. As long as the hydrogen is produced electrochemically, the electricity could also stem from nuclear, coal, or other nonrenewable power sources.

Not any company involved in hydrogen production is eligible for the limitation. $\S 64 a$ EEG 2021 only applies to companies active in the sector "production of industry gases" ( $\S$ 64a EEG 2021, annex 4, No. 78). Additionally, the production has to constitute the largest portion of the total added value of the company.

In case an undertaking is eligible for limitation or exemption according to both $\S 64 \mathrm{a}$ and $\S 69$ b EEG 2021, they have to decide for which one to apply. Both regulations are mutually exclusive (§ 12i (1) EEV). Only one of the regulations can be applied throughout the year. It is albeit possible to switch to the other one in the following year, and back the year after that.

$\S \S$ 61a ff. EEG 2021: Exemptions for self-provision

Another Possibility for an Exemption from the EEG Surcharge Is Offered by $\S \S 61 \mathrm{a} f f$. EEG 2021.The exemptions apply to entities operating their own power generating facilities, without the electricity passing through the power grid (§ 3 No. 19 EEG 2021). In terms of green hydrogen production, these exemptions would benefit hydrogen projects if they produce their own electricity with renewable sources. The requirement that the electricity has to be self-produced and may not have been passed through the power grid means that the exemptions of $\$ \S 61 \mathrm{a} f$. EEG 2021 cannot be met by many companies [39]. In case an electrolyzer is operated by an industrial hydrogen consumer, partial savings on electricity cost may be achieved by using renewable energy from their own renewable energy source production plants.

\subsection{Political Developments in Germany: The National Hydrogen Strategy}

The growing attention for hydrogen as an energy carrier is reflected by the fact that the German Federal Government has released its own hydrogen strategy, the National Hydrogen Strategy [6]. While it is a communication that is not legally binding, it does reflect the governments' goals which can be indicative of coming legislation. The National Hydrogen Strategy was issued in June 2020. It outlines its goals within the context of the energy transition and the German 2030 Climate Action Plan as well as the fact that Germany is committed to achieving greenhouse gas (GHG) neutrality [6]. The goal for GHG neutrality has recently been set higher (from 2050 to 2045) through $\S 3$ (2) of the Federal Climate Protection Act [40] and is not reflected in the current version of the NHS, which as of now cites the 2030 Climate Action Plan with GHG neutrality for 2050 [41]. The Strategy further states that fossil fuels have to be replaced by alternative energy sources and that hydrogen will play a key role in this endeavor [6]. The Strategy in this respect names uses of hydrogen as an energy carrier (e.g., for fuel-cell-powered vehicles); as an instrument in sector coupling, especially in energy applications that cannot be electrified; and as an energy storage medium. The strategy also states the goal of replacing grey hydrogen with green hydrogen in industrial processes that use grey hydrogen today [6]. The last part relates to an important factor of the German hydrogen strategy: It focuses exclusively on green hydrogen [6]. It can be said that it regards only green hydrogen to be "sustainable in the long term" [6], although turquoise hydrogen is also mentioned [6]. Within 
these conditions, the strategy aims to make hydrogen a "competitive option", to develop a "domestic market for hydrogen technology" in Germany, "establishing hydrogen as an alternative for other energy sources" and making it "a sustainable base for the industrial sector" [6]. Via the strategy, the federal government also announces wide-ranging financial support for the promotion and deployment of green hydrogen technology [6].

\section{Discussion}

In the following, we discuss the role of green hydrogen in the German energy system. Is green hydrogen supported by the current legal framework (Section 4.1), i.e., the Energy Industry Act and the Renewable Energies Act including its amendments? Which future developments can be drawn from the political National Hydrogen Strategy (Section 4.2)?

\subsection{Hydrogen in the Current Legal Framework}

The current legal framework for (green) hydrogen is the result of some recently adopted changes in legislation: The EEG 2021 was adopted (and in its wake, the EEV was amended) and the EnWG was amended as well in 2021. These laws now explicitly mention hydrogen. This is remarkable as, until 2021, there were no regulations directly addressing hydrogen or electrolyzers. Lawyers mostly had to interpret existing regulations, for the qualification of hydrogen; e.g., "Does hydrogen qualify as natural gas/biogas?", "Under which conditions is hydrogen a renewable energy carrier?". The characteristics of hydrogen as an energy carrier and a means of storing and converting electricity did not fit into some regulations. This was especially discussed when it came to questions of unbundling: Since green hydrogen is a gas that is produced from electricity, it is technically associated somewhere between the natural gas sector and the electricity sector, and it was for a long time ambiguous which sector it "belonged" to. The recent legislation is a step forward as it addresses hydrogen and hydrogen production directly. This provides legal certainty for network operators, investors, and regulatory authorities alike. This certainty is especially important for investors and potential operators or electrolyzers.

The legal framework does not, however, provide a coherent, overall regulation for hydrogen production [42]. As shown above, any definition of "green hydrogen", or hydrogen as biogas, is only relevant within the scope of the respective act. For example, the definition of green hydrogen as given in the EEV is only relevant for the exemption from the EEG surcharge according to § 69b EEG 2021. So far, there is no single and overall valid legal definition of what green hydrogen exactly is and what it qualifies for.

The aforementioned exemptions from grid access charges ( $\$ 118$ EnWG) and from the EEG surcharge ( $\S 64 a$ and $\S 69$ b EEG 2021) provide support for the production of green hydrogen in Germany. Another factor for the competitiveness of green hydrogen production is carbon pricing [42]. While the price of carbon does not directly affect the hydrogen production process, an increase in the carbon price could level the playing field between grey and green hydrogen and would make green hydrogen financially more interesting for industrial companies. The German legislator will have to examine whether the current way of carbon pricing is efficient or whether it has to be adjusted in scope and price, as some have suggested that the carbon price in Germany is not high enough [42,43]. This can also be addressed in the European Union's emissions trading system at the same time.

The legislation passed in 2020 and 2021 shows that the German legislator regards hydrogen, especially green hydrogen, as a relevant factor for the German energy industry. As a result, the current legislation is overall more supportive of green hydrogen than in recent years.

\subsubsection{Hydrogen in the Energy Industry Act}

The EnWG has had several amendments adopted in 2021. It now addresses hydrogen and regulates its use in the German energy system. This in itself is an important step forward. The new definition of energy storage facilities ( $\$ 3$ No. 15d) encompasses 
electrolyzers. This definition as well as the new definition of (natural) gas, energy, and biogas ( $\$ 3$ No. 10f, 14 and 19a EnWG) now addressing hydrogen open the door for regulation of (green) hydrogen and its production. The EnWG thus regulates not only green hydrogen, but also other kinds of hydrogen. The regulations differ, however, since the general regulations regarding hydrogen apply to any "color" of hydrogen. Only hydrogen produced through electrolysis using electricity from renewable sources qualifies as biogas. Consequently, any regulation within the EnWG regarding biogas applies to green hydrogen. Whether or not the regulations are in themselves beneficial, the EnWG now provides a clearer legal framework for any entity planning to produce hydrogen. With the technique of encompassing hydrogen into already existing terms (natural gas, biogas), the legislator also was able to employ the already existing regulation as opposed to creating an overall new framework.

One criticism pertaining to the new definitions of natural gas and energy could be that they only apply to hydrogen as far as it is fed into the grid or used for grid-bound energy supply ( $\$ 3$ No. 14, 19a EnWG). This is consistent within the framework of the EnWG because this prerequisite also applies to natural gas and other energy carriers [15]; however, one interesting feature of hydrogen is that it is not dependent on the gas grid, but can be transported in other ways.

The EnWG now holds several important regulations with regard to unbundling (see above), giving potential operators of electrolyzers the much-needed legal certainty for their business. Generally, the fact that network operators are not allowed to own or operate electrolyzers is probably going to be supportive of a market launch for hydrogen production. There has been some criticism of the exceptions to those rules. Any employment of electrolyzers can potentially interfere with the energy market.

Generally, while there are good arguments for allowing NOs to operate PtG plants regarding grid safety, it would be inconsistent with the current legal framework. Since the delineation between competitive and system-based measures would be blurred, there would be a certain risk of market distortion. The benefits of $\mathrm{PtG}$ for grid operation could probably also be reaped if the plants were operated not by NOs, but by competitive undertakings.

\subsubsection{Hydrogen in the Renewable Energies Act and Its Amendment}

The amendments of the EEG 2021/Renewable Energies Act could well make the production of green hydrogen economically more viable. As stated above, a major concern was (or is) the high cost of electricity in Germany, mainly due to a number of publicly imposed charges. This problem is partially solved by the regulations in $\S 69 \mathrm{~b}$ and also $\S$ 64a EEG 2021 as they give a possibility to limit or be exempted from the EEG surcharge. Both state no conditions for the usage of the hydrogen produced and thus also apply to hydrogen produced for electricity/energy storage. Both regulations are relatively new and a necessary step towards promoting hydrogen as a means for energy storage.

It is worth analyzing the regulation in the EEV. Many of the detailed requirements regarding § 69b EEG 2021 are left to the EEV. The overall possibility of an exemption from the EEG surcharge is beneficial. The detailed instructions and the definition as to what green hydrogen is within the scope of the EEG 2021 are also positive: they provide legal certainty for PtG plant operators, investors, and government agencies. This being said, the requirements are quite restrictive since only the first 5000 full-load hours per year are exempted. Any electricity used after/beyond the first 5000 full-load hours is charged with the full EEG surcharge.

\subsection{The National Hydrogen Strategy}

Since the National Hydrogen Strategy (NHS) is a political strategy, it is not legally binding and does in itself not yield any consequences for entities dealing with hydrogen. As mentioned above, the strategy focuses on green hydrogen, as the German Federal Government only sees green hydrogen as sustainable [29]. It is coherent that the strategy then focuses on green hydrogen since it sees hydrogen as one possibility of decarbonization 
and of reducing Germany's greenhouse gas emissions [29]. The NHS addresses some regulatory barriers in the promotion of green hydrogen production. By the time this paper was written, some of the regulation which was in place when the NHS was issued had already been amended.

The NHS acknowledges the problem of the current high cost of hydrogen production. The high cost of electricity-especially the price components induced by regulation-is addressed. The NHS names as one of several measures "a fair design of price components induced by the state" [29]. The NHS promises an analysis as to how the production of green hydrogen can be exempted from taxes, levies, or charges. The exemption from the EEG surcharge is specifically mentioned as one goal. Here, the strategy addresses one central regulatory problem regarding hydrogen production and has specific measures to solve it.

Another measure is the exploration of model projects of cooperations between operators of electrolyzers and network operators [29]. Since these have to be in line with the unbundling regulations, the NHS states that the government will explore the need for possibly amending the regulatory framework. The aim here is to "ease the burden" on the grid. A general clarification of the status of electrolyzers in the unbundling regulations is not the goal here; this could also be a sign that the government sees no need for clarification. This proposal is on the one side supportive of green hydrogen since it aims to enable the production of hydrogen. On the other hand, the operation of electrolyzers by network operators always involves the danger of market distortion. Therefore, this measure could not be supportive for the market launch of green hydrogen in the long run. This measure is also one of the few instances where the NHS indirectly mentions green hydrogen as an energy storage medium. Remarkably, the strategy almost does not mention the possibility of green hydrogen as an energy storage medium. This is on the one hand surprising because energy storage is a crucial challenge in the promotion of renewable energy sources. Green hydrogen could be an important storage medium here. On the other hand, the technology and the financial side of hydrogen as an energy storage medium are not yet on a level where it could be widely employed for storage.

The Strategy promises several measures to foster the development of a hydrogen market, some of which could be beneficial for green hydrogen production (e.g., introducing carbon dioxide pricing for fossil fuels and possible exemption from taxes, levies, and surcharges for green hydrogen production) [6]. Measures such as the support of electrolyzers for industrial procedures could indirectly also be beneficial for the economic viability of hydrogen energy storage since they might bring down prices for electrolyzers by promoting their production on a mass scale. Overall, the NHS addresses regulatory barriers for green hydrogen and suggests concrete and probably promising measures.

\section{Conclusions and Outlook}

German legislation has made significant progress in the last two years in terms of the regulation of green hydrogen as an energy carrier. Two central acts in German energy law - the EnWG and the EEG 2021-now explicitly address and categorize hydrogen, providing legal certainty for plant operators and network operators. One hindrance in the production of green hydrogen is the high electricity price. This has been addressed through exemptions from grid tariffs and the EEG. The regulatory framework is confined to the scope of the respective acts, meaning there is no comprehensive regulation of green hydrogen production in German law yet.

The newly formed German federal government includes green hydrogen in its coalition agreement [44]. In line with the current NHS, the focus remains on green hydrogen. Among other goals, the new government aims to make Germany a lead market for hydrogen technologies and promote the production of green hydrogen. The coalition agreement does not make any direct announcements regarding new regulation, apart from promising purchasing quotas for public agencies [44]. The coalition agreement also promises to achieve competitive electricity prices for German companies; this would have to involve 
some legislation as the electricity prices in Germany are in a large part regulation-driven by charges, levies, and taxes [17].

The European Hydrogen Strategy (EHS) [45] will also further play a role as it shapes European legislation which, in turn, informs German national legislation. It is worth pointing out one difference in their terminology: The NHS focuses on green hydrogen and uses the terminology described in Section 3.1. The EHS however uses the following two terms: (a) "renewable" or "clean" hydrogen that is produced via water electrolysis using electricity from renewable sources and (b) "low-carbon" hydrogen which is fossil-based hydrogen with carbon capture or electricity-based hydrogen regardless of the electricity source [45]. Why the Commission chose this terminology is not entirely clear. It could be suggested that the aim is to shift policies in a new direction-possibly to "blur the line between 'green' and 'blue' hydrogen, essentially defining both as 'clean'" [46]. In this case, the German and the European strategies differ in a key point, and it remains open how this will shape the future German legislation regarding hydrogen.

New legislation is also to be expected from the European Union-and subsequently on the German level where it will have to be transposed. The European Commission has issued a draft to amend the current Renewable Energy Directive (RED II) [47]. The proposed amendment for the so-called RED III [48] was issued by the Commission in July 2021; it includes a quota for the member states for hydrogen used in industry: by 2030, $50 \%$ of the hydrogen used for industry purposes has to be contributed by renewable fuels of nonbiological origin [48]. If and when this proposal is passed, this quota will inform the German legislation on hydrogen and possibly be a promotor of green hydrogen in the future.

Author Contributions: Conceptualization and methodology, L.M.R., J.S., N.B.; formal analysis, L.M.R.; investigation, resources, visualization, L.M.R., J.S., N.B.; writing-original draft preparation, L.M.R.; writing—review and editing, J.S., N.B.; supervision, R.A., K.G. All authors have read and agreed to the published version of the manuscript.

Funding: This research received no external funding.

Institutional Review Board Statement: Not applicable.

Acknowledgments: The authors would like to thank Eadbhard Pernot, Christian Hampel, Elina Martens, Manfred Lange, and Frank Burmeister.

Conflicts of Interest: The authors declare no conflict of interest.

\section{References}

1. Leicher, J.; Schaffert, J.; Cigarida, H.; Tali, E.; Burmeister, F.; Giese, A.; Albus, R.; Görner, K.; Carpentier, S.; Milin, P.; et al. The Impact of Hydrogen Admixture into Natural Gas on Residential and Commercial Gas Appliances. Energies 2022, 15, 777. [CrossRef]

2. Creos; DESFA; Elering; Enagás; Energinet; Eustream; FGSZ; Fluxys Belgium; Gasgrid Finland; Gasunie; et al. Extending the European Hydrogen Backbone-A European Hydrogen Infrastructure Vision Covering 21 Countries 2021. Available online: https:/ / gasforclimate2050.eu/wp-content/uploads/2021/06/European-Hydrogen-Backbone_April-2021_V3.pdf (accessed on 20 November 2021).

3. Energiewirtschaftsgesetz Vom 7. Juli 2005 (BGBl. I S. 1970, 3621), Das Zuletzt Durch Artikel 84 Des Gesetzes Vom 10. August 2021 (BGBl. I S. 3436) Geändert Worden Ist; [Energy Industry Act of 7 July 2005 (Federal Law Gazette I, p. 1970, 3621), as Last Amended by Article 84 of the Act of 10 August 2021 (Federal Law Gazette I, p. 3021)]. Available online: https:/ /www.gesetze-im-internet.de/enwg_2005 /BJNR197010005.html (accessed on 24 January 2022).

4. Erneuerbare-Energien-Gesetz Vom 21. Juli 2014 (BGBl. I S. 1066), Das Zuletzt Durch Artikel 11 Des Gesetzes Vom 16. Juli 2021 (BGBl. I S. 3026) Geändert Worden Ist; [Renewable Energies Act of 21 July 2014 (Federal Law Gazette I, p. 1066), as Last Amended by Article 11 of the Act of 16 July 2021 (Federal Law Gazette I, p. 3026)]. 2021. Available online: https:/ /www.gesetze-im-internet.de/eeg_2014/BJNR1 06610014.html (accessed on 20 November 2021).

5. Erneuerbare-Energien-Verordnung Vom 17. Februar 2015 (BGBl. I S. 146), Die Zuletzt Durch Artikel 87 Des Gesetzes Vom 10. August 2021 (BGBl. I S. 3436) Geändert Worden Ist); [Renewable Energies Ordinance of 17 February 2015 (Federal Law Gazette I, p. 146), as Last Amended by Article 87 of the Act of 10 August 2021 (Federal Law Gazette I, p. 3436)]. Available online: https://www.gesetze-iminternet.de/ausglmechv_2015/BJNR014610015.html (accessed on 24 January 2022). 
6. Federal Ministry for Economic Affairs and Energy. The National Hydrogen Strategy; Federal Ministry for Economic Affairs and Energy: Berlin, Germany, 2020.

7. Taibi, E.; Blanco, H. Hydrogen Series-Part 2: Green Hydrogen Cost Reduction: Scaling up Electrolysers to Meet the $1.5^{\circ} \mathrm{C}$ Climate Goal; IRENA: Abu Dhabi, United Arab Emirates, 2021.

8. Pinsky, R.; Sabharwall, P.; Hartvigsen, J.; O'Brien, J. Comparative Review of Hydrogen Production Technologies for Nuclear Hybrid Energy Systems. Prog. Nucl. Energy 2020, 123, 103317. [CrossRef]

9. Boretti, A. Technology Readiness Level of Solar Thermochemical Splitting Cycles. ACS Energy Lett. 2021, 6, 1170-1174. [CrossRef]

10. Albrecht, U.; Altmann, M.; Barth, F.; Bünger, U.; Fraile, D.; Lanoix, J.; Pschorr-Schoberer, E.; Vanhoudt, W.; Weindorf, W.; Zetra, M.; et al. Study on Hydrogen from Renewable Resources in the EU-Final Report; Ludwig-Bölkow-Systemtechnik (LBST): Ottobrunn, Germany; Brussels, Belgium, 2015.

11. Fujishima, A.; Honda, K. Electrochemical Photolysis of Water at a Semiconductor Electrode. Nature 1972, 238, 37-38. [CrossRef] [PubMed]

12. Binder, M.; Kraussler, M.; Kuba, M.; Luisser, M. Hydrogen from Biomass Gasification. Available online: https://www. ieabioenergy.com/wp-content/uploads/2019/01/Wasserstoffstudie_IEA-final.pdf (accessed on 20 November 2021).

13. Parkinson, B.; Balcombe, P.; Speirs, J.F.; Hawkes, A.D.; Hellgardt, K. Levelized Cost of $\mathrm{CO}_{2}$ Mitigation from Hydrogen Production Routes. Energy Environ. Sci. 2019, 12, 19-40. [CrossRef]

14. Kerscher, F.; Stary, A.; Gleis, S.; Ulrich, A.; Klein, H.; Spliethoff, H. Low-Carbon Hydrogen Production via Electron Beam Plasma Methane Pyrolysis: Techno-Economic Analysis and Carbon Footprint Assessment. Int. J. Hydrog. Energy 2021, 46, 19897-19912. [CrossRef]

15. Abánades, A.; Rubbia, C.; Salmieri, D. Thermal Cracking of Methane into Hydrogen for a $\mathrm{CO}_{2}$-Free Utilization of Natural Gas Int. J. Hydrog. Energy 2013, 38, 8491-8496. [CrossRef]

16. Dagle, R.A.; Dagle, V.; Bearden, M.D.; Holladay, J.D.; Krause, T.R.; Ahmed, S. An Overview of Natural Gas Conversion Technologies for Co-Production of Hydrogen and Value-Added Solid Carbon Products; Pacific Northwest Natl Lab(PNNL): Richland, WA, USA, 2017.

17. International Renewable Energy Agency (IRENA). A Renewable Energy Perspective; IRENA: Abu Dhabi, United Arab Emirates, 2019.

18. Böhm, H.; Zauner, A.; Rosenfeld, D.C.; Tichler, R. Projecting Cost Development for Future Large-Scale Power-to-Gas Implementations by Scaling Effects. Appl. Energy 2020, 264, 114780. [CrossRef]

19. Schmidt, O.; Gambhir, A.; Staffell, I.; Hawkes, A.; Nelson, J.; Few, S. Future Cost and Performance of Water Electrolysis: An Expert Elicitation Study. Int. J. Hydrog. Energy 2017, 42, 30470-30492. [CrossRef]

20. Thema, M.; Bauer, F.; Sterner, M. Power-to-Gas: Electrolysis and Methanation Status Review. Renew. Sustain. Energy Rev. 2019, 112, 775-787. [CrossRef]

21. Van Hulst, N. The Clean Hydrogen Future Has Already Begun; International Energy Agency: Paris, France, 2019; Available online: https://www.iea.org/commentaries/the-clean-hydrogen-future-has-already-begun (accessed on 12 October 2021).

22. Borning, M. Bringt die Nationale Wasserstoffstrategie endlich die passende Regulierung? EnergieRecht 2020, 04/20, $135-143$.

23. Federal Ministry for Economic Affairs and Energy (BMWi). Energy Prices and Transparency for Consumers. 2021. Available online: https:/ / www.bmwi.de/Redaktion/EN/Textsammlungen/Energy/electricity-prices.html (accessed on 22 October 2021)

24. Federal Ministry for Economic Affairs and Energy (BMWi). Das Erneuerbare-Energien-Gesetz. Available online: https://www. erneuerbare-energien.de/EE/Redaktion/DE/Dossier/eeg.html (accessed on 4 November 2021).

25. Directive2009/28/EC of the European Parliament and of the Council of 23 April 2009 on the Promotion of the Use of Energy from Renewable Sources and Amending and Subsequently Repealing Directives 2001/77/EC and 2003/30/EC (Text with EEA relevance), OJ L 140, 5.6.2009, p. 16-62. Available online: https:/ / eur-lex.europa.eu/LexUriServ/LexUriServ.do?uri=OJ:L:2009:140:0016:0062:en:PDF (accessed on 24 January 2022).

26. Elspas, M.; Graßmann, N.; Rasbach, W. Energiewirtschaftsgesetz (EnWG); Erich Schmidt Verlag (ESV): Berlin, Germany, 2018.

27. Gesetzentwurf der Fraktionen der CDU/CSU und FDP-Entwurf eines Gesetzes zur Neuregelung energiewirtschaftsrechtlicher Vorschriften; BT-DRs. 17/6072; Deutscher Bundestag: Berlin, Germany, 2011.

28. Kreeft, G. Legislative and Regulatory Framework for Power-to-Gas in Germany, Italy and Switzerland; STORE\&GO Project: Groningen, The Netherlands, 2018; pp. 22-28.

29. European Comission Third Energy Package. Available online: https://ec.europa.eu/energy/topics/markets-and-consumers/ market-legislation/third-energy-package_en\#unbundling (accessed on 15 June 2021).

30. Borning, M. Der Schlüssel für die Energiewende Wartet auf die Passende Regulierung. EnergieRecht 2020, 03/20. Available online: https://erdigital.de/field/Autoren/q/\%22Martin+Borning\%22/truncation/0/suche.html (accessed on 24 January 2022).

31. Entwurf Eines Gesetzes zur Umsetzung Unionsrechtlicher Vorgaben und zur Regelung Reiner Wasserstoffnetze im Energiewirtschaftsrecht; Gesetzesentwurf der Bundesregierung, BT-Drs. 19/27453; Bundesregierung: Berlin, Germany, 2021.

32. Bundesnetzagentur (National Grid Agency). Beschlusskammer 4, Beschluss Vom 27.01.2021, Az. BK4-19-049; Bundesnetzagentur: Cologne, Germany, 2021. Available online: https://www.bundesnetzagentur.de/DE/Beschlusskammern/1_GZ/BK4-GZ/2019 /BK4-19-0049/BK4-19-0049_Beschluss_download_bf.pdf?_blob=publicationFile\&v=2 (accessed on 9 November 2021).

33. Sieberg, C.; Cesarano, C. Rechtsrahmen für eine Wasserstoffwirtschaft. Recht Energ. 2020, 6, 238. 
34. Erneuerbare-Energien-Gesetz vom 21. Juli 2014 (BGBl. I S. 1066), das zuletzt durch Artikel 11 des Gesetzes vom $16 . \quad J u l i$ 2021 (BGBl. I S. 3026) geändert worden ist" / Englisch: Renewable Energies Act of 21 July 2014 (Federal Law Gazette I, p. 1066), as last amended by Article 11 of the Act of 16 July 2021 (Federal Law Gazette I, p. 3026). Available online: https:/ / www.bgbl.de/xaver/bgbl/start.xav?start=\%2F\%2F*[\%40attr_id\%3D\%27bgbl114s1066.pdf\%27]\#_bgbl_\%2F\% 2F*\%5B\%40attr_id\%3D\%27bgbl114s1066.pdf\%27\%5D_1646034210817 (accessed on 24 January 2022).

35. Bundesministerium für Justiz. Biomasseverordnung vom 21. Juni 2001 (BGBl. I S. 1234), die uletzt durch Artikel 8 des Gesetzes vom 13. Oktober 2016 (BGBl. I S. 2258) geändert worden ist. 2016. Available online: https:/ /Www.Gesetze-Im-Internet.de/ Biomassev / (accessed on 24 January 2022).

36. Gesetz zur Neuregelung des Rechts der Erneuerbaren Energien im Strombereich und zur Änderung damit Zusammenhängender Vorschriften vom 25. Oktober 2008. BGBl. I S. 2074. Available online: https://www.bgbl.de/xaver/bgbl/start.xav?startbk=Bundesanzeiger_ BGBl\&start=/ /*\%255B@attr_id=\%27bgbl108s2074.pdf\%27\%255D\#_bgbl_\%2F\%2F*\%5B\%40attr_id\%3D\%27bgbl108s2074. pdf\%27\%5D_1646034140825 (accessed on 24 January 2022).

37. Federal Ministry for Economic Affairs and Energy (BMWi). State-Imposed Components of the Electricity Price. Available online: https:/ / www.bmwi.de/Redaktion/EN/Artikel/Energy/electircity-price-components-state-imposed.html (accessed on 9 November 2021).

38. Kraft-Wärme-Kopplungsgesetz vom 21. Dezember 2015 (BGBl. I S. 2498), das Zuletzt Durch Artikel 88 des Gesetzes vom 10. August 2021 (BGBl. I S. 3436) geändert worden ist; [Combined Heat and Power Act of 21 December 2015 (Federal Law Gazette I p. 2498), as Last Amended by Article 88 of the Act of 10 August 2021 (Federal Law Gazette I p. 3436)]. Available online: https://www.bmwi.de/Redaktion/DE/Downloads/G/gesetzesentwurf-zur-aenderung-der-bestimmungen-zurstromerzeugung-aus-kwk-und-eigenversorgung.pdf?_blob=publicationFile\&v=4 (accessed on 28 January 2022).

39. Buchmüller, C. Die energie- und regulierungsrechtlichen Baustellen auf dem Weg zur Wasserstoffwirtschaft. Zeitschrift für Umweltrecht. 2021, 4, 195. Available online: https:/ / www.zur.nomos.de/archiv/2021/heft-4/ (accessed on 28 January 2022).

40. Bundes-Klimaschutzgesetz vom 12. Dezember 2019 (BGBl. I S. 2013), das durch Artikel 1 des Gesetzes vom 18. August 2021 (BGBl. I S. 3905) geändert worden ist 2019. Available online: https:/ /Www.Gesetze-Im-Internet.de/Ksg/BJNR251310019.Html (accessed on 28 January 2022).

41. German Federal Government. Klimaschutzprogramm 2030 Der Bundesregierung Zur Umsetzung Des Klimaschutzplans 2050; German Federal Government: Berlin, Germany, 2019. Available online: Https://Www.Bundesfinanzministerium.de/Content/DE/ Downloads/Klimaschutzprogramm-2030-Der-Bundesregierung-Zur-Umsetzung-Des-Klimaschutzplans-2050.Pdf?_blob= publicationFile\&v=2 (accessed on 24 January 2022).

42. Hoffmann, B.; Halbig, A.; Senders, J.; Nysten, J.V.; Antoni, O.; Müller, T. Auf dem Weg zum Wasserstoffwirtschaftsrecht? In Stift. Umweltenergierecht, WürzburgerStudien zum Umweltenergierecht, No. 21, 2021; 2021; p. 54. Available online: https:/ / stiftung-umweltenergierecht.de/wp-content/uploads/2021/07/Stiftung_Umweltenergierecht_Wuerzburger-Studiezum-Umweltenergierecht_21_Wasserstoffwirtschaftsrecht_2021-07-12-2.pdf (accessed on 24 January 2022).

43. McKinsey \& Company, Hydrogen Council: Hydrogen Insights a Perspective on Hydrogen Investment, Market Development and Cost Competitiveness: February 2021. Available online: https://hydrogencouncil.com/wp-content/uploads/2021/02/ Hydrogen-Insights-2021-Report.pdf (accessed on 16 January 2022).

44. Mehr Fortschritt Wagen-Bündnis für Freiheit, Gerechtigkeit und Nachhaltigkeit. Koalitionsvertrag 2021-2025; Zwischen der Sozialdemokratischen Partei Deutschlands (SPD); Bündnis 90/Die Grünen und den Freien Demokraten (FDP): Berlin, Germany, 2021.

45. European Commission. Communication from the Commission to the European Parliament, the Council, the European Economic and Social Committee and the Committee of the Regions: A Hydrogen Strategy for a Climate-Neutral Europe; Brussels, Belgium, 2020. Available online: https:/ / ec.europa.eu/energy/sites/ener/files/hydrogen_strategy.pdf (accessed on 16 February 2022).

46. Fleming, R. Clean or Renewable-Hydrogen and Power-to-Gas in EU Energy Law. J. Energy Nat. Resour. Law 2020, $39,43-63$. [CrossRef]

47. Directive (EU) 2018/2001 of the European Parliament and of the Council of 11 December 2018 on the Promotion of the Use of Energy from Renewable Sources (Text with EEA Relevance). 2018, Volume OJ L 328, pp. 82-209. Available online: https:/ / Eur-Lex.Europa.Eu/ Legal-Content/En/TXT/PDF/?Uri=CELEX:32018L2001 (accessed on 23 January 2022).

48. Proposal for a Directive of the European Parliament and of the Council, Amending Directive (EU) 2018/2001 of the European Parliament and of the Council, Regulation (EU) 2018/1999 of the European Parliament and of the Council and Directive 98/70/EC of the European Parliament and of the Council as Regards the Promotion of Energy from Renewable Sources, and Repealing Council Directive (EU) 2015/652, Brussels, 14 July 2021, Volume COM(2021) 557 Final. Available online: https: / / eur-lex.europa.eu/legal-content/EN/TXT/?uri=CELEX\%3A52021PC0557 (accessed on 20 January 2022). 